\title{
Giant pelvic-perineal leiomyoma simulating a malignant lesion.
}

Papa Abdoulaye Bâ ${ }^{1 *}$, Doudou Gueye ${ }^{2}$, Thomas Marcel Mbar Wade ${ }^{1}$, Jacques Noel Tendeng ${ }^{3}$, Mohamed Lamine Diao ${ }^{3}$, Anne Aurore Sankale ${ }^{4}$, Mamadou Cissé ${ }^{5}$, Ibrahima Konaté ${ }^{2}$.

${ }^{1}$ General Surgery Unit of Regional Hospital, Faculty of Medicine, Thiès University, Thiès, Senegal.

${ }^{2}$ Department of Pediatric Surgery, Albert Royer Hospital, Senegal.

${ }^{3}$ Department of General Surgery, Regional Hospital of Saint Louis, Faculty of Health Sciences at the University Gaston Berger Saint Louis, Senegal.

${ }^{4}$ Department of Plastic Surgery, Aristide Le Dantec Hospital, Cheikh Anta Diop University, Dakar, Senegal.

${ }^{5}$ Department of General and Digestive Surgery, Aristide Le Dantec Hospital, Cheikh Anta Diop University, Dakar, Senegal.

*Corresponding author: Papa Abdoulaye Bâ, MD, Professor, General Surgery Unit of Regional Hospital, Faculty of Medicine, Thiès University, Thiès, Senegal, BP: 34 A Thiès

Received Date: April 05, 2021; Accepted Date: April 23, 2021; Published Date; May 08, 2021

Citation: Papa A Bâ, Gueye D, Thomas M M Wade, Jacques N Tendeng, Mohamed L Diao, Anne A Sankale, Cissé M, Konaté I. (2021) Giant pelvic-perineal leiomyoma simulating a malignant lesion. J. Surg Case Repo and Imag. 4(4); DOI:10.31579/2690-1897/071

Copyright: (C) 2021 Papa Abdoulaye Bâ, This is an open-access article distributed under the terms of the Creative Commons Attribution License, which permits unrestricted use, distribution, and reproduction in any medium, provided the original author and source are credited

\section{Abstract}

Introduction: Soft tissue tumors are benign or malignant lesions developing from connective tissue and its varieties.

Case Report: A 35-year-old patient referred to us for management of a voluminous pelvic-perineal mass. The clinical and para clinical data were in favor of a malignant lesion. The treatment consisted of a wide excision of the tumor. The post-operative period was complicated by an anal incontinence needing a protective left iliac colostomy. A perinioraphy, sphincter refection, and re-establishment of the digestive continuity were performed later on. The cytological examination of the excised mass revealed a conclusive involute hyanilised leiomyoma.

Conclusion: This contrast between the clinical, para clinical and histologic data in our patient confirm the diagnostic challenges of soft tissue tumors, hence the need for special technic to assure diagnostic certitude to avoid mutilating surgical approaches for a benign lesion.

Keywords: Leiomyoma, soft tissue tumors, perineal, surgery

\section{Introduction}

Soft tissue tumors are benign or malignant lesions developing from connective tissue and its differentiated varieties which are adipose tissue, muscular tissue, vascular tissue, synovial and fascial, as well as the tissue enveloping nerve peripheral cells [1].

The benign tumors are a 100 times more frequent than malignant ones [2,3]. However, faced with a soft tissue tumor, the first objective is to think of a sarcoma of the soft tissue.

We report a case of a voluminous pelvic-perineal mass. The clinical and para-clinical data were in favor of a malignant lesion contrasted by cytological examination which revealed a benign tumor, the leiomyoma type.

\section{Case report}

A case report of a 35 years old female presented at the surgical department for the management of a voluminous tumor of the pelvic - perineal area which developed for a period of about 4 years. This mass caused a lot of discomfort in the sitting position, wearing clothing, and sexual relationships as result causing psychosocial problems.

The patient had undergone an excision of the same mass 4 years ago. This surgery was followed by a recurrence of the tumor. A cytological examination was not done.

On admission in our hospital the patient was in good general condition. Physical examination demonstrated a flabby, non-tender mass, measuring $24 \mathrm{~cm}$ the widest diameter, emanating from the left buttocks with an anal extension and at the level left labia majora (Figure 1). The pelvic exam revealed a bulging into the left cal de sac. We did neither notice any urinary or sphincter problems. 


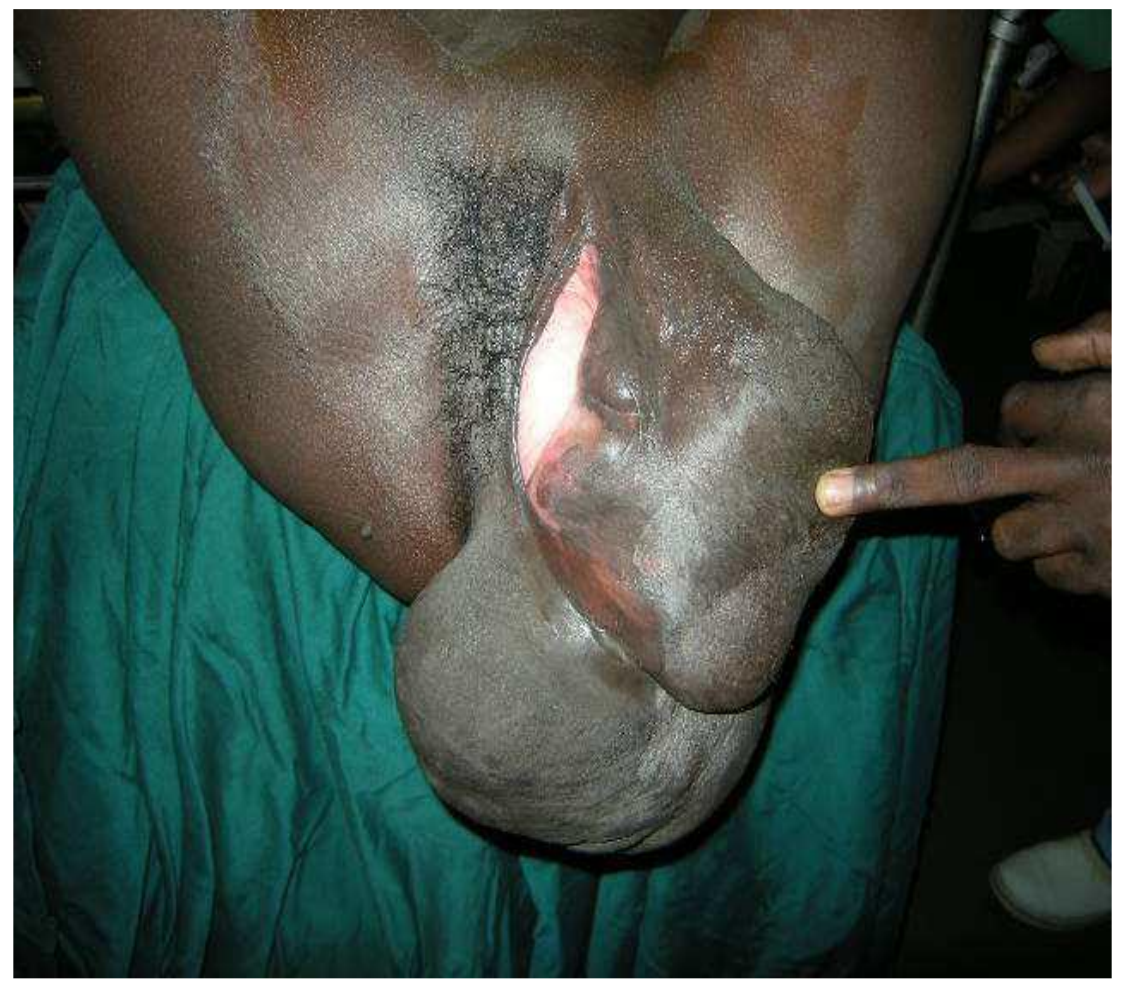

Figure 1: Tumor genito-gluteal, front view

The CT scan suggested a tumoral process with a progressive potential impact to the genital region invading in an obstructive way the ureters, the bladder the rectum. Magnetic resonance imaging showed a voluminous multi lobular pelvic - perineal mass suggestive of an angioma, schwanoma or a sarcoma (Figure 2).

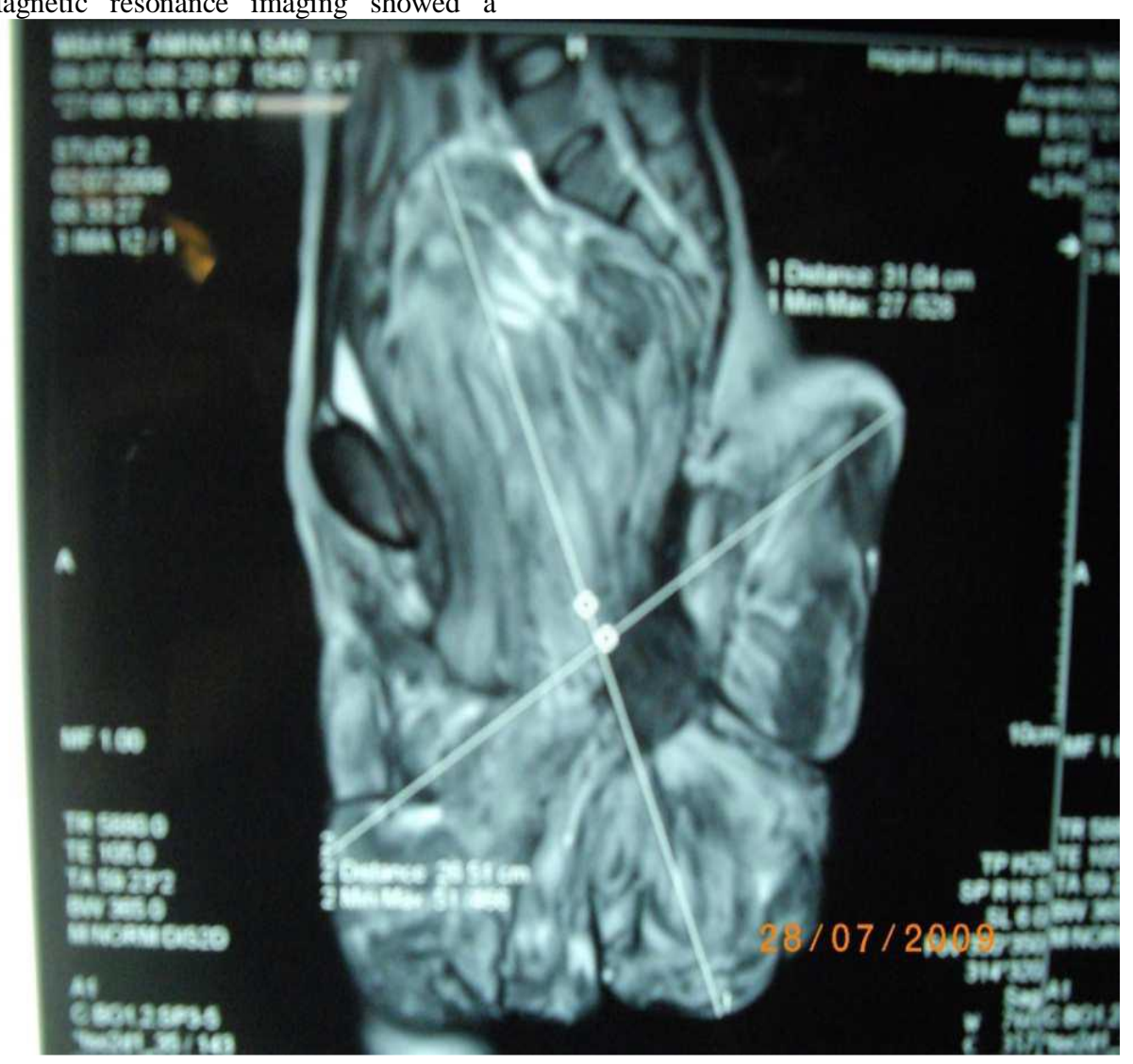

Figure 2: MRI snapshot showing malignancy of at the obturator region. 
The treatment was surgical and consisted of wide excision of the tumor with partial section of the external anal sphincter, the levator ani and coccygeal hamstrings muscles. Repair of muscle, sphincter, by advancement and rotation skin flaps was performed. The post-operative period was complicated by an anal incontinence needing a protective left iliac colostomy. A perinioraphy, sphincter refection, and re- establishment of the digestive tube continuity were performed later on. The outcomes were favorable with good anal continence and complete healing.

Cytological examination of the surgical specimen concluded an involute hyalinized leiomyoma (Figure 3).

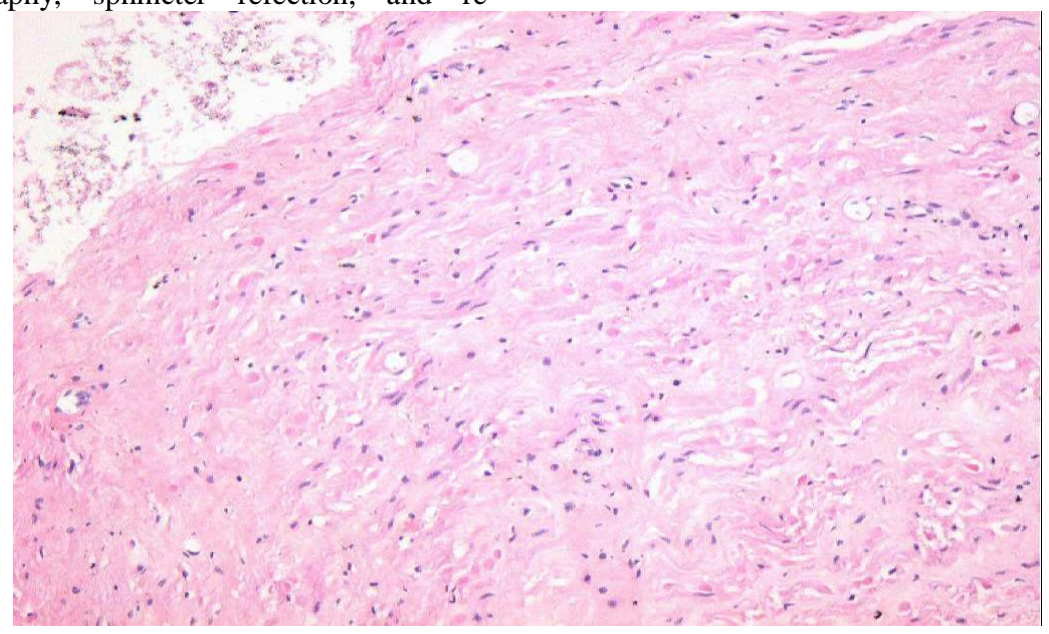

Figure 3: Microscopic view of the tumor.

After a period of 4 years, there has been no recurrence (Figure 4).

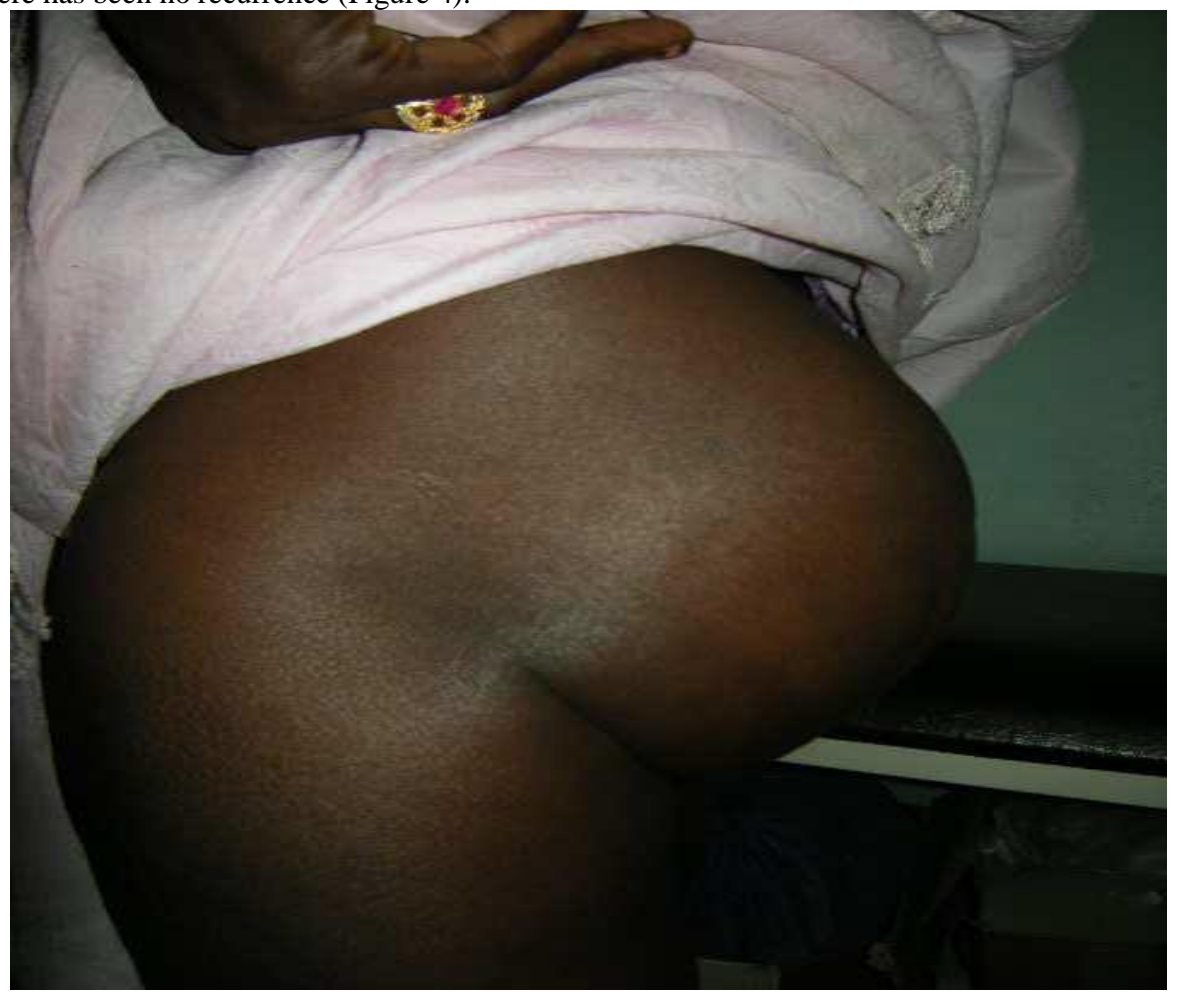

Figure 4: side view of the buttocks after healing.

\section{Discussion}

Leiomyomas are rare tumors as evidenced by the series of 1331 benign soft tissue tumors published by Myhre-Jensen where they represent only $3.8 \%$ [4]. They are cutaneous or superficial tumors originating from the erector muscles of hair follicles in particular areas of extension of the limbs or smooth muscle present in the deep dermis, in the genital areas.
In the work of Wibner [5], nearly $60 \%$ of soft tissue tumors are located at the extremities and the genital location in the second place. In our patient, the localization was the base of the lower limb at the buttocks and genital extension.

Clinically, the tumoral, painless syndrome is the most frequent reason for seeking consultation in the series of Ackerman, 50\% [6]. This painless character explains the delay in seeking consultation. 
Enziger and Weiss have shown that there is no consistent safe proof extract from the examination that can distinguish between benign and malignant, showing the difficulty in diagnosis of these tumors [3].

MRI provides major topographic and semiological arguments but is not specific enough for the diagnosis of malignancy.

Tumors with a diameter greater than $50 \mathrm{~mm}$, and the height greater than $66 \mathrm{~mm}$, are often suspicious for malignancy [7].

Thus in our patient, MRI having found a multi-layered lesion measuring $31 \mathrm{~cm}$ high, $26 \mathrm{~cm}$ anterior-posterior diameter and the transverse axis of $18 \mathrm{~cm}$ suggests a potentially progressive tumor. However, definitive diagnosis remains a matter of histology [8].

Wide excisions should be preferred instead of marginal resections which are always inadequate, more so intracapsular resections that are nothing else than simple surgical biopsies [9].

Histologically, deep leiomyomas are large tumors, well-circumscribed, pseudo-encapsulated, whitish-Grey and with neither atypical changes, mitosis or necrosis. Myxoid and / or cystic modifications are common [4].

For our part, despite clinical and para clinical data suggestive of malignancy, there was no evidence of mitotic activity at microscopy of the surgical specimen which is in favor of a leiomyoma.

Recurrence observed in our patient after an initial excision is probably due to incomplete excision.

\section{Conclusion}

Soft tissues tumors present themselves in form of a painless, tissular mass. Management is best decided in a specialized collegial type manner, given the rarity, multiple histological types and possible clinical presentations. This will reduce misdiagnosis and avoid mutilating surgery in case of benign lesion.

\section{Conflict of interest}

Authors declare no conflict of interest.

\section{Acknowledgements}

The authors thank Doctor Adamson Phiri, medical doctor, for the translation of this article.

We do declare no conflict of interest. All authors have read and approved this clinical case.

\section{References}

1. Bonvalot S, Vanel D, Terrier P, Le Pechoux C, Le Cesne A. (2004). Principes du traitement des sarcomes des tissus mous de l'adulte. Encyclopédie Médico-Chirurgicale. Techniques chirurgicales Orthopédie-Traumatologie; 6:521-541.

2. Blum A, Louis M, Lecocq M, Detraille R. (2008). Comment j'explore une tumeur des parties molles ? Journal de radiologie; 89:1243-44.

3. Weiss SW, Sobin LH. (1994). Histologic typing of soft tissue tumors (International classification of tumors). Springer Verlag; Berlin.

4. Myhre-Jensen O. (1981). A consecutive 7 year series of 1331 benign soft tissue tumors. Clinicopathologic data comparison with sarcoma. Acta Orthop. Scand; 52: 287-93.

5. Wibmer C, Leithner A, Zielonke N, Sperl M, Windhager R. (2010). Increasing incidence rates of soft tissue sarcomas? A populationbased epidemiologic study and literature review. Ann Oncol; 21: 1106-11.

6. Ackerman, Pegato's. (2000). Sarcoma of the soft tissue. Cancer; 3: 917- 936.

7. De Schepper AM, DeBeuckeleer L, Vandevenne J, Somville J. (2000). Magnetic resonance imaging of soft tissue tumors. Eur Radiol; 10:213-223.

8. Taieb S, Ceugnart L, Gauthier H, Penel N, Vanseymortier L. (2006). Sarcomes des tissus mous des extrémités. Rôle de l'imagerie dans la prise en charge initiale. Cancer/Radiothérapie;10:22-33.

9. Coindre JM, Terrier P, Guillou L, Le Doussal V, Colin F, et al. (2001). Predictive value of grade for metastasis development in the main histologic types of adult soft tissue sarcomas. A study of 1240 patients from the French Federation of cancer Centers. Cancer; 91:1919-26.
This work is licensed under Creative Commons Attribution 4.0 License

\section{To Submit Your Article Click Here: Submit Manuscript}

DOI: $10.31579 / 2690-1897 / 077$

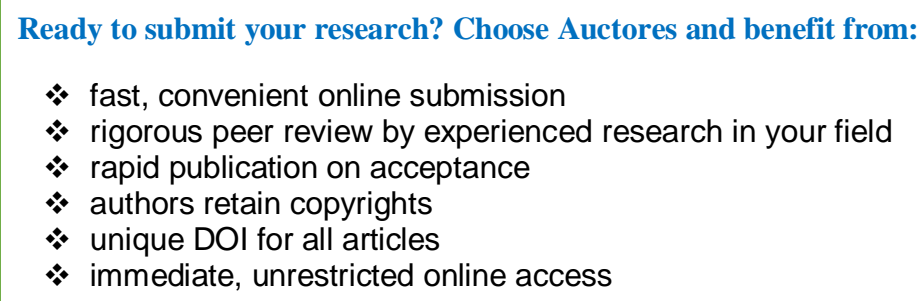

Ready to submit your research? Choose Auctores and benefit from:

* fast, convenient online submission

* rigorous peer review by experienced research in your field

* rapid publication on acceptance

* authors retain copyrights

* unique DOI for all articles

* immediate, unrestricted online access

At Auctores, research is always in progress.

Learn more www.auctoresonline.org/journals/journal-of-surgical-casereports-and-images 